\title{
Impact of Protean Career Orientation on Academics' Career Success: The Mediating Role of Psychological Capital
}

\author{
Mohammed Mustafa ${ }^{1,2^{*}}$, Mohammed Nazri Mohd Nor ${ }^{1}$, Safiah Omar \\ ${ }^{1}$ Policy and Business Strategy, University of Malaya, Kuala Lumpur, 50603, MALAYSIA \\ ${ }^{2}$ College of Business Studies, Sudan University of Science and Technology, Khartoum, 407, SUDAN \\ *Corresponding e-mail
}

DOI: https://doi.org/10.30880/jtmb.2019.06.02.006

Received: 13 December 2018 Accepted: 3 January 2019 Available online: 30 June 2019

\begin{abstract}
Most people seek success in their career due to the prominent role of career in shaping their lifestyle from the first day they started working with organization. However, some people feel unsuccessful in their career. Hence. the main purpose of this study is to investigate the mediating role of psychological capital (PsyCap) between protean career orientation (PCO) and career success. Further, this study is quantitative in nature based on primary data which were collected from full-time lecturers teaching in Sudanese public universities. Out of the 250 self-administrated questionnaires, 209 were returned for final analysis. The data obtained were analyzed by using the Smart-PLS 3.2.6 software techniques. Besides the context of this study, another uniqueness of this study was with the model in which career success was assessed as a formative construct. However, in the past studies, it was assessed as a reflective construct. The findings indicated that PsyCap was not only an important predictor of career success in the academic atmosphere, but it also played a positive mediator between PCO and career success. The paper closed with implications and conclusion.
\end{abstract}

Keywords: Academics' career success, psychological capital, positive psychology, and protean career orientation.

\section{Introduction}

In the last two decades, the concept of career success (CS) has attracted much attention from scholars (Santos \& Santos, 2016). This is due to the general recognition of the significant effect of career success at the workplace on both employee behavior and organization outcome (Arthur et al., 2005; Ballout, 2007). Career success is believed to increase an employee's self-esteem, commitment, engagement, and is tagged as a competent identity to a specific area of the career work (Hall \& Chandler, 2005). It also has a positive effect on the employees' feeling at work as it brings life satisfaction and happiness (Abele, Hagmaier, \& Spurk, 2016). Thus, when an organization devotes considerable efforts towards an employee's career success, this can contribute to organizational success (Ng, Eby, Sorensen, \& Feldman, 2005). For example, if an employee achieved his/her success in career will be more satisfied to continue working with his/her organization. That not only reduces the turnover intention rate but also increases the level of employee's commitment as well as he/she remains a productive and active employee as well (van Dierendonck \& van der Gaast, 2013). Initially, career success has been explored based on two schools of thought that traditional and contemporary schools. The traditional school focused on identifying the individual or organizational factors that may have a crucial effect on career success in general ( $\mathrm{Ng}$ et al., 2005). Meanwhile, the contemporary school differentiates between careers typology. That based on solid argumentation is that every career is unique and affected by various factors related to the nature of the career (Hall, 2004). Moreover, Abele et al. (2011) explained that career success is a contextual phenomenon shaped according to the occupation that is under study. For example, the medical career success varies from career success in the academia. People who are in medicine operationalize their career success in terms of their salary, promotion, and a number of surgeries have done in hospitals. In contrary, people in the academic environment perceive certain parameters that have a considerable weight in evaluating their career success. The parameters are salary, promotion, number of publications and peer review (Abele et al., 2011). 

The purpose of this study is to first create a career success model for the academic world, such as the Sudanese public universities, based on the contemporary career approach (i.e., protean career theory, Hall et al., 2018). Second, this study focuses on the mediating role being played by psychological capital to provide more interpretation on the relationship between protean career theory and academics career success at the workplace. Finally, this study serves to close the gap as there is a lack of studies that use a combination of career success dimensions. The use of this combination gives a clear picture of career success.

\section{Literature Review}

\subsection{Career Success Overview}

Initially, the career concept arose from studies about occupations and job perspectives. This was evident in the studies before the 1950s such as the work of Hughes (1937), who studied the institutional office and the person, and homeless men which was researched by Anderson and Park (1923). However, after the 1950s, scholars focused their attention on the career notion. For example, theorists explain that a career is not only a job or occupation but it also involves a process which is lifelong whereby the career actually establishes how one wants to live his or her own life (Reardon, Lenz, Sampson, \& Peterson, 1999, P. 3). Hughes (1958) explained that the career concept became visible when the industrialization and the bureaucratic procedures take place in the administration of organizations. As for the latter, some people depend on the employer (organization) for their career development. This is because career development is a process approach. It involves promotion, job security, job satisfaction and career performance (Shen et al., 2015). The career development process is expected to lead to the success of both the employee and the organization. Hence, the scholars of career have identified the measurements of career success phenomenon which are objective and subjective success. Objective career refers to the extrinsic or tangible motivations that are experienced by individuals during their career and career progress (i.e., salary and promotion). These extrinsic motivations are controlled by the organization (Arthur et al., 2005). On the other hand, the individual employee has control of the subjective career progress. This refers to the employee's individual feeling towards his or her job and career. This feeling is called job and career satisfaction, which is derived from the employee's intrinsic or internal motivation (Ng \& Feldman, 2014).

In general, career success is defined as "the positive psychological or work-related outcomes or achievements one accumulates as a result of work experiences" (Seibert, Crant, \& Kraimer, 1999). Comprehensively, the career success concept is comprised of the objective (e.g., salary and promotion) and subjective (job and career satisfaction) indicators. Nonetheless, in the past, career's scholars supported the traditional school of career which had more interest in the objective career more than the subjective career (Arthur et al., 2005; Ng \& Feldman, 2014). Accordingly, career success phenomenon was also investigated from the objective side only (Arthur et al., 2005; Hall, 1996; Ng et al., 2005; Vos \& Soens, 2008). In contrast, the contemporary researchers focused intensively on the subjective indicators of career success (Colakoglu, 2011; Ng \& Feldman, 2014; Ngo, Foley, Ji, \& Loi, 2014). Unfortunately, the literature that combines the two components of career success (i.e., objective and subjective) is still scarce and needs more investigation. This statement was made even though objective career success might has a positive effect on subjective career success, and visa-versa (Abele \& Spurk, 2009a). Interestingly, there is a recent scholarly work which stresses on the importance of combining the dimensions of the two constructs as this achieves and reflects a full picture of career success in the workplace for both the individual and organization (Abele \& Spurk, 2009a; Otto, Roe, Sobiraj, Baluku, \& Garrido Vásquez, 2017). Besides, the common sense of employees who perceive their success in career relying on these two indicators (i.e., objective and subjective success), otherwise, they feel unsuccessful because of achieving one side of their success in career whether is objective or subjective. Regardless, although there are a plethora of career success studies, very rarely have researchers investigated on the mediating role of psychological capital on the relationship between the protean career and academics career success (Abu Said et al., 2015).

\subsection{Protean career orientation and career success}

The concept of protean was derived from the Greek sea-god called "Proteus" (Haber \& Bertone, 2016) which means a strong individual ability to deal with the changing environment by coping with what one is doing currently in a career (Khan, Salleh, \& Hemdi, 2016). In other words, protean career is "an orientation that enables an individual to adapt to social, political, technological, and economic changes across the individual's multiple career life cycles" (Hall, Yip, \& Doiron, 2018, p. 6.4). The protean career orientation (PCO) is comprised of two essential attitudes, namely selfdirected; and values-driven or intrinsic work values (Hall et al., 2018). Self-direction refers to the degree in which one has control over one's own career. In other words, the individual is confident to do well in his/her career (Briscoe \& Hall, 2006). This confidence will increase the individual's ability to adapt learning in a new environment to cope with current and future challenges at the workplace. On the other hand, a values-driven perspective directs the attention to one's internal values as that is a true guidance and standard to gain success in a career (Briscoe \& Hall, 2006). As 
mentioned earlier, the concept of PCO is about an individual who is responsible for and has control over his/her career (Hall et al., 2018).

The new theory of protean career has been suggested by Hall (1976) because of the violation of the psychological contract obligation towards employees' perception of career success which are job security, training, and promotion. Ever since, contemporary employers now look for meta-skilled employees who are able to self-manage and selfprogress in their career (Granrose \& Baccili, 2006). However, according to Granrose and Baccili (2006), a majority of employees still uphold traditional career goals such as job security and upward mobility. This is because they believe some organizations have failed to acknowledge and materialize employees' perception of career success which are job security, training, and promotion. In turn, this will lead to a decrease in their organizational commitment and increase their turnover intention (Granrose \& Baccili, 2006). Therefore, an alternative choice for employees is to adopt a PCO for achieving success in their career. Gubler, Arnold, and Coombs (2014) argued that PCO mostly focuses on an individual's motives to achieve his/her career success by following a particular career path. In support, previous studies demonstrated that PCO plays an important role in predicting employees' career success. However, the previous research works only focused on evaluating the relationship between PCO and subjective career success rather than objective career success. Hall (2004) specified the connection of the PCO to the subjective/psychological career success, which is about valuing individual work responsibility and freedom growth in the career path. Certain studies have recorded a positive association between PCO and subjective career success (Volmer \& Spurk, 2011).

In addition, Vos and Soens (2008) investigated the impact of PCO on subjective career success indicators (i.e., career satisfaction and perceived employability) among 289 Belgian employees. The results showed that PCO has a positive relationship with subjective career success. In another study, Volmer and Spurk (2011) examined the relationship between PCO and both subjective and objective career success indicators, among 116 borderless career attitude professionals in Germany. The results revealed that to a certain extent, PCO is more related to subjective career success than objective career success. However, there are mixed results, when some studies revealed that PCO is positively related to objective career success (e.g. Abele \& Spurk, 2009b and Volmer \& Spurk, 2011). Back to Volmer and Spurk (2011), the findings indicate that individuals with protean career attitude reported a higher level of subjective and objective (salary) career success. The above result was congruent with Valcour and Ladge (2008) who investigated the protean expectations of mothers with subjective and objective career success. They found that the traditional and protean perspectives are integrated; hence have a positive effect on women's career success and their career income as well (i.e., objective measure). All these occurrences initially started from subjective career success. On the other hand, Hall (2004) describes the PCO as the "career learning cycle", which means that a person with a protean career mindset will seek to achieve psychological success. As such, this learning cycle stimulates self-management behaviour in one's career (Vos \& Soens, 2008). As a result of that, the individual becomes more consistent and optimistic with his/her job's tasks that related to the current situation (Volmer \& Spurk, 2011). In support, scholars confirmed that PCO has a positive relationship with salary, self-efficacy, proactive personality, and proactive career behavior (Abele \& Spurk, 2009b; Briscoe et al., 2006; Herrmann, Hirschi, \& Baruch, 2015).

In contrast, a few studies found that PCO was not related to some indicators of objective career success. For example, the author may find that PCO is not related to salary or promotion only. This explains that PCO is related to overall objective career success but not for specific one based on the situation and context of study. Accordingly, Abessolo, Andreas, and Jérôme (2017) found that PCO was positively related to intrinsic, social, and status work values, but negatively related to extrinsic or material work values (Abessolo, Andreas, \& Jérôme, 2017). However, Valcour and Ladge (2008) argued that there is a link between extrinsic and intrinsic indicators of career success because some variables may affect the subjective career success through their impact on the objective career outcomes. To confirm this point, Stumpf and Tymon (2012) found a strong influence of past promotions, but less influence of salary changes on subjective career success. Therefore, Vos and Soens (2008) called upon future researches to include objective career success as an important outcome for PCO. Besides, their suggestion of investigation to the role of PCO on both forms of career success (i.e., objective and subjective success) for clarifying the missed understanding of the complete image for overall career success. Consequently, there are some studies attempted to follow the stated suggestion. For example, Kiong and Yin-Fah (2016), who studied the impact of PCO on career success in Malaysia. The results showed that PCO was positively related to employees' career success (Kiong \& YinFah, 2016).

In one hand, from the practical side, the scholars of career development have stressed that PCO has a positive relationship with internal and external career success as well as with other positive career outcomes (Direnzo et al., 2015; Grimland et al., 2012). On the other hand, form the theoretical side, Hall and his colleagues in 2018 published a model of protean career theory (PCT) which explained that career success represents an important outcome for PCO in the workplace (Hall et al., 2018). Based on the stated evidence, the previous studied have intensively focused in the direct relationship between PCO and career success outcomes. However, this research study attempts to investigate the indirect relationship between PCO and career success outcomes (objective and subjective) due to the lack of studies that addressing this issue. Besides the bulk of PCO's literatures were exist in the Western context (e.g., Abele \& Spurk, 2009b and Volmer \& Spurk, 2011), although the extending roots of career success's problem in Eastern context particularly in Sudanese context. 


\subsection{PCO and Psychological Capital (PsyCap)}

Over the past two decades, PCO has emerged due to the turbulent business environment and globalization which resulted to the psychological contract shifted from an organizational basis into an individual basis. This shift in the career structure has encouraged individuals to be more responsible for their career (Hall, 1996, 2004). In order to fit into the current scenario of PCO, individuals need to understand that they should set their own goals for their career so that they are able to see their lives in the long-term perspective and feeling satisfied (Sen \& Hooja, 2015). Such career orientation requires an intrinsic positive motivation, for example, psychological capital, to persuade the individual to achieve his or her anticipated goals. The psychological capital (PsyCap) may help the individual to overcome challenges that arise during the course of achieving his or her career goals (Sen \& Hooja, 2015).

PsyCap contains four golden dimensions which are hope, efficacy, resilience, and optimism (HERO). All these dimensions act as motivators for the individual to gain success. Prior studies have also identified a key feature of the self-directed approach which is proactive (Briscoe \& Hall, 2006; Vos \& Soens, 2008). Hence, when an individual has a PCO (self-directed) oriented and proactive, he/she needs to have more self-efficacy, hope, resilience, and optimism in order to achieve career success. To date, a few studies have examined the relationship between PCO and PsyCap (i.e., Krishna, 2016; Rowe, 2013; and DiRenzo, 2011). In US, DiRenzo and Greenhaus (2011) found a strong correlation between PCO and PsyCap via career planning. He also mentioned that PsyCap was related to the subjective career success and work-life balance. This result was congruent with Rowe (2013) who found that PsyCap directly affected the PCO dimensions (self-directed and values-driven) as a whole. On the contrary, Krishna (2016) uncovered a partial relationship between PsyCap and PCO. But this study looked at the effect of PsyCap on PCO. More recently, DiRenzo and his colleagues (2015) have established that PCO positively leads to career capital (human, social, and psychological capital). However, this research was concerned with investigating the relationship between PCO and PsyCap in the non-Western context (Direnzo, Greenhaus, \& Weer, 2015). H1: PCO is positively related to PsyCap.

\subsection{PsyCap and Career Success}

Psychological capital (PsyCap) came into existence in the last decade, the introducer was Luthans and Youssef in (2004). It is defined as "an individual's positive psychological state of development" (Schulz et al., 2014, p. 623). It is also considered as the most important construct that contributed to the positive psychology movement (Seligman, 2000). Since then, PsyCap has been used in studying several outcomes such as career success and work-life balance (DiRenzo, 2010), as well as performance and satisfaction (Luthans et al., 2007). Consequently, the empirical evidence has established that PsyCap has a strong effect on an individual's career success and the other positive outcomes in the workplace. Additionally, DiRenzo (2010) found that PsyCap has significantly predicted employability, career success, and work-life balance. In other words, an employee who is high on PsyCap is expected to be more successful in his career and committed to continue working with the organization over a longer period. Moreover, PsyCap is comprised of four valuable constructs (confidence or self-efficacy, hope, optimism, and resilience) from the perspective of positive organizational behavior (POB) (Luthans et al., 2004).

Past literature showed that there is a positive relationship between PsyCap and career success. Accordingly, Luthans et al. (2007) investigated the relationship between psychological capital and performance and satisfaction of 174 management students in Midwestern University in the United States. The results revealed that there was a positive relationship between PsyCap and performance and job satisfaction. Also, they added that the four components of PsyCap combined as interrelationships provided a better predictor of those outcomes than investigated one by one. In a different context, Luthans, Avolio, Walumbwa, and Li (2005) investigated the relationship between psychological capital and performance of 422 workers in China. The results indicated that workers have positive states regarding hope, optimism, and resiliency separately and collectively together which confirms that all these resources can be tested as higher order construct (Luthans et al., 2005).

Similarly, Karatepe and Karadas (2015) investigated the effect of psychological capital on job, career and life satisfaction, mediated by work engagement, conducted in four- and five-star hotels in Bucharest, capital of Romania. The results showed that optimism appears to be the best indicator of psychological capital, followed by resilience, selfefficacy, and hope. Further, the findings indicated that employees with a high level of psychological capital are more committed and satisfied with their job, career, and life (Karatepe \& Karadas, 2015). In support, Schulz et al. (2014) found that individuals who possess high on psychological capital enjoy "higher levels of job satisfaction, commitment to their organization, and most importantly are less likely to quit" (Schulz, Luthans, \& Messersmith, 2014, p. 628). Overall, the findings of previous studies clearly showed that PsyCap is a lead for career success. H2: PsyCap is positively related to career success. 


\subsection{The mediation effect of PsyCap}

Although there is strong evidence to indicate that PCO is associated with career success, little is known about the mechanisms of that relationship. In this regard, the self-determination theory (SDT) assumes that individual factors are linked to key individual-level outcomes generated via the inner drive or intrinsic motivation (Ryan and Deci, 2011). This inner drive for work is PsyCap in this research, that encourages the achievement of something (Gulyani \& Bhatnagar, 2017) such as career success. Additionally, because of this inner drive, employees become proactive. As a result, they manage their career effectively and obviously become more satisfied with their career compared to those with passive career attitude (Volmer, Spurk, 2011). Thus, the self-determination theory suggests that intrinsically motivated employees are those that initiate accomplishment and achievement of career and organizational goals respectively (Ryan, 2016). In line with this, Volmer, Spurk (2011) argued that self-directed attitude is rewarded only by companies that value autonomy and proactive behavior. Thus, individuals with high PCO are expected to possess the self-determination to initiate career development and enhancement (Briscoe et al., 2006).

Interestingly, previous studies showed there is a possible mediation of PsyCap between PCO and career success. For example, Rienzo and Greenhaus (2011) and DiRenzo et al. (2015) have emphasized that PsyCap has a central role in bridging PCO and positive work and life outcomes. Moreover, PsyCap has been verified of this role from different career aspects. For example, according to Karatepe \& Karadas (2015), who found that PsyCap has a positive effect on career success, whereas, DiRenzo and Greenhaus (2011) and DiRenzo et al (2015) have initiated examining PsyCap as a mechanism between PCO and positive work and life outcomes. We can refer to this mechanism as a resource and the ability of this resource in generating additional resources. The mechanism mentioned is obviously the basic tenet of the conservation of resources (COR) theory (Hobfoll, 1989). Hence, introducing the mechanism such as PsyCap resources (hope, efficacy, resilience, and optimism) between PCO and career success, that lead in generating other personal resources to achieve one's career success (Hobfoll, Johnson, Ennis, \& Jackson, 2003). In essence, Hall and his colleagues in their model of protean career process in 2018 (p. 6.6), have emphasized the importance of personal resources to be used as the mechanism for PCO to achieve career success in the workplace. Therefore, based on the COR and SDT theory as well as empirical evidence, PsyCap has been potentially selected to act as the mechanism for the relationship of PCO and career success. H3: PsyCap mediates the relationship between PCO and career success.

\subsection{Research Framework}

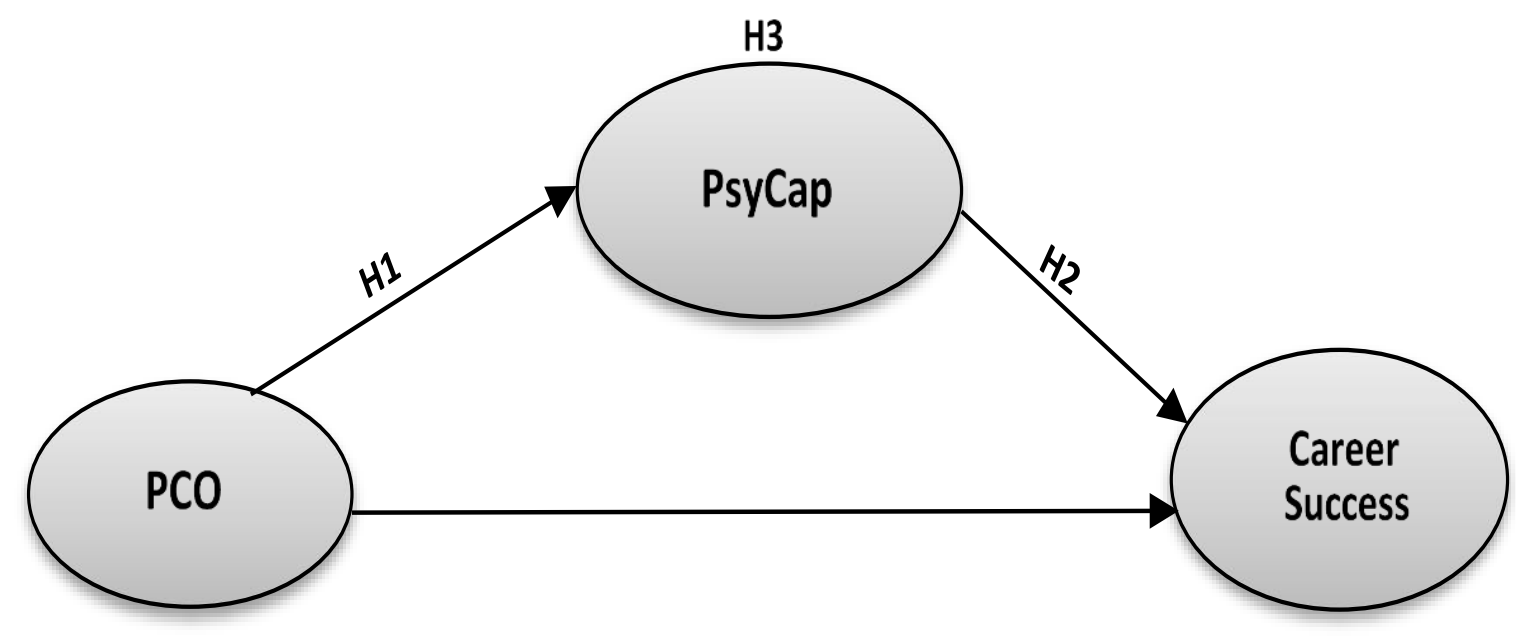

Fig. 1 - Articulating the theoretical model of this study.

\section{Methodology}

\subsection{Population, Sample size, and Data Collection}

The population of this study were the academic staff who working full-time in public universities in Sudan. In order to achieve the purpose of this study, data were collected from the top 5 public universities in Sudan (i.e., Khartoum university, Sudan university, Al Gazira university, Omdurman Islamic university, and Al Neelain university) using a self-administered questionnaire. To calculate the sample size, the authors applied the $G^{*}$ power 3.1 software (Erdfelder, FAul, Buchner, \& Lang, 2009) with the following setting: $f 2=0.15$ (medium), $\alpha=0.05$, number of predictors $=2$ and the power was set at $80 \%$ (Gefen, Rigdon, \& Straub, 2011; Ringle, Da Silva, \& Bido, 2014). The sample size required to test the model was 68 , but this number tripled to 204 in order to have a good 
size effect. The data were collected by distributing 50 questionnaires to each of the 5 universities providing us with a total sample size of 250 which is a better representation of the population of interest. The questionnaire was divided into 3 sections; section (A) involves the information about career success, section (B) includes the information about PsyCap and PCO) and finally section (C) reflects the information about the demography. On the other hand, the questionnaire items have been adapted from different validated sources specially Q1 journals. Where in, four (4) items to measure objective career success adapted from (Abu Said et al., 2015) whereas, five (5) items adapted from (Greenhaus, Parasuraman, \& Wormley, 1990) for measuring subjective career success. In addition, twenty-four (24) items for measuring PsyCap validated by (Luthans et al., 2007), and finally PCO has twelve (12) items adapted from (Briscoe \& Hall, 2006). The respondents were asked to indicate their agreement or disagreement on several statements using the five-point Likert scale ranging from $1=$ strongly disagree to $5=$ strongly agree.

\subsection{Profile of Respondents}

The demographics of the respondents are specified in Table 1. Males (64.6\%) outnumbered females (35.4\%). A majority of the respondents possess a Master's degree (47.8\%) and Ph.D. (45.0\%). This is due to the requirement to be a lecturer in public universities in Sudan. Most of the respondents are located in Khartoum and Sudan University (316\% and 29.2\%) respectively. These are top two universities in Sudan and have more students compared with the other universities.

Table 1 - Profile of Respondents.

\begin{tabular}{|c|c|c|c|}
\hline Profile & & Frequency & Percentage \\
\hline \multirow[t]{2}{*}{ Gender } & Male & 135 & 64.6 \\
\hline & Female & 74 & 35.4 \\
\hline \multirow{4}{*}{ Age } & Less than 25 & 15 & 7.2 \\
\hline & $25-35$ & 81 & 38.8 \\
\hline & $36-45$ & 67 & 32.1 \\
\hline & More than 45 & 46 & 22.0 \\
\hline \multirow{3}{*}{ Marital status } & Single & 69 & 33.0 \\
\hline & Married & 134 & 64.1 \\
\hline & Divorced & 6 & 2.9 \\
\hline \multirow{4}{*}{$\begin{array}{l}\text { Level of } \\
\text { Education }\end{array}$} & Bachelor's degree & 14 & 6.7 \\
\hline & Master's degree & 100 & 47.8 \\
\hline & $\mathrm{PhD}$ & 94 & 45.0 \\
\hline & Other (specify) & 1 & .5 \\
\hline \multirow{4}{*}{ Experience } & Less than 5 years & 52 & 24.9 \\
\hline & $5-10$ & 58 & 27.8 \\
\hline & $11-15$ & 43 & 20.6 \\
\hline & More than 15 years & 56 & 26.8 \\
\hline \multirow{6}{*}{ University } & University of Khartoum & 66 & 31.6 \\
\hline & Sudan University of Science and & 61 & 29.2 \\
\hline & Technology & 36 & 17.2 \\
\hline & University of Gezira & & \\
\hline & Al-Neelain University & 28 & 13.4 \\
\hline & Omdurman Islamic University & 18 & 8.6 \\
\hline
\end{tabular}

\subsection{Control variables}

As the previous studies revealed the importance of controlling some demographic variables which have strong effect on career success such as gender, working experience, and age (Ng, Eby, Sorensen, \& Feldman, 2005; Volmer \& Spurk, 2011).

\section{Analysis and Results}

For testing the model of this study, the Partial Least Squares (PLS) technique was used by applying the SmartPLS 3.2.6 software (Ringle, Wende, \& Becker, 2015). We followed the recommended two-stage analytical 
procedure for measuring both reflective and formative constructs (Anderson \& Gerbing, 1988; Ramayah, Lee, \& In, 2011). Accordingly, we conducted the measurement model test for assessing the validity and reliability of constructs. Then, we performed the examination of the structural model for testing the hypotheses of this model (Ramayah, Jasmine, Ahmad, Halim, \& Rahman, 2017). In addition, we used a bootstrapping technique (5000 resamples) for assessing the significance of the path coefficients and outer loadings (Hair, Hult, Ringle, \& Sarstedt, 2017).

\subsection{Reflective Measurement Model Analysis}

There are two types of validity performed for assessing the measurement model which are convergent validity and discriminant validity.

\subsubsection{Convergent Validity}

The convergent validity of the reflective measurement model is usually assessed by examining the factor loadings, average variance extracted (AVE) and composite reliability (CR) (Hair, Sarstedt, Hopkins, \& Kuppelwieser, 2014; Tehseen, Sajilan, Gadar, \& Thurasamy, 2017). For this model, the factor loadings were almost equal to 0.7 and higher; the composite reliability of each construct was higher than 0.7 ; and the AVE of all constructs were also higher than 0.5 , as suggested in the literature (see Table 2).

Table 2 - Assessment of AVE, CR, Cronbach's Alpha, and Rho_A.

\begin{tabular}{|c|c|c|c|c|c|c|c|c|}
\hline Second order & $\begin{array}{c}\text { Frist } \\
\text { order/ } \\
\text { dimensions }\end{array}$ & Items & Measure & $\begin{array}{c}\text { Factor } \\
\text { Loadings }\end{array}$ & $\begin{array}{c}\text { Cronbach's } \\
\text { Alpha }\end{array}$ & rho_A & $\begin{array}{c}\text { Composite } \\
\text { Reliability } \\
\text { (CR) }\end{array}$ & $\begin{array}{c}\text { Average } \\
\text { Variance } \\
\text { Extracted } \\
\text { (AVE) }\end{array}$ \\
\hline \multirow{18}{*}{$\begin{array}{c}\text { Psychological } \\
\text { Capital }\end{array}$} & \multirow[t]{4}{*}{ Hope } & Ho1 & \multirow[t]{18}{*}{ Reflective } & 0.75 & \multirow[t]{4}{*}{0.776} & \multirow[t]{4}{*}{0.781} & \multirow[t]{4}{*}{0.856} & \multirow[t]{4}{*}{0.599} \\
\hline & & Ho3 & & 0.763 & & & & \\
\hline & & Ho4 & & 0.737 & & & & \\
\hline & & Ho5 & & 0.837 & & & & \\
\hline & \multirow{6}{*}{$\begin{array}{l}\text { Self- } \\
\text { efficacy }\end{array}$} & $\mathrm{Se} 1$ & & 0.713 & \multirow[t]{6}{*}{0.846} & \multirow[t]{6}{*}{0.847} & \multirow[t]{6}{*}{0.886} & \multirow[t]{6}{*}{0.565} \\
\hline & & $\mathrm{Se} 2$ & & 0.739 & & & & \\
\hline & & $\mathrm{Se} 3$ & & 0.772 & & & & \\
\hline & & $\mathrm{Se} 4$ & & 0.816 & & & & \\
\hline & & $\mathrm{Se} 5$ & & 0.741 & & & & \\
\hline & & Se6 & & 0.727 & & & & \\
\hline & \multirow[t]{4}{*}{ Resilience } & Re1 & & 0.812 & \multirow[t]{4}{*}{0.77} & \multirow[t]{4}{*}{0.787} & \multirow[t]{4}{*}{0.851} & \multirow[t]{4}{*}{0.59} \\
\hline & & $\operatorname{Re} 2$ & & 0.817 & & & & \\
\hline & & Re4 & & 0.738 & & & & \\
\hline & & $\operatorname{Re} 5$ & & 0.698 & & & & \\
\hline & \multirow[t]{4}{*}{ Optimism } & Op3 & & 0.77 & \multirow[t]{4}{*}{0.803} & \multirow[t]{4}{*}{0.803} & \multirow[t]{4}{*}{0.871} & \multirow[t]{4}{*}{0.629} \\
\hline & & Op4 & & 0.803 & & & & \\
\hline & & Op5 & & 0.83 & & & & \\
\hline & & Op6 & & 0.768 & & & & \\
\hline \multirow{10}{*}{$\begin{array}{c}\text { Protean } \\
\text { Career } \\
\text { Orientation }\end{array}$} & Self- & SD1 & \multirow[t]{10}{*}{ Reflective } & 0.742 & \multirow[t]{6}{*}{0.874} & \multirow[t]{6}{*}{0.877} & 0.905 & 0.615 \\
\hline & \multirow[t]{5}{*}{ Directed } & SD2 & & 0.793 & & & & \\
\hline & & SD3 & & 0.838 & & & & \\
\hline & & SD4 & & 0.768 & & & & \\
\hline & & SD5 & & 0.77 & & & & \\
\hline & & SD6 & & 0.789 & & & & \\
\hline & Values- & VD1 & & 0.798 & 0.858 & 0.861 & 0.904 & 0.702 \\
\hline & driven & VD2 & & 0.892 & & & & \\
\hline & & VD3 & & 0.846 & & & & \\
\hline & & VD4 & & 0.813 & & & & \\
\hline Career & Objective & Promotion & Reflective- & 0.905 & 0.894 & 0.898 & 0.927 & 0.761 \\
\hline Success & & Publications & Formative & 0.816 & & & & \\
\hline & & Pay & & 0.82 & & & & \\
\hline & & Position & & 0.941 & & & & \\
\hline & Subjective & Subjective1 & & 0.807 & 0.807 & 0.836 & 0.866 & 0.568 \\
\hline & & Subjective2 & & 0.826 & & & & \\
\hline
\end{tabular}




\subsubsection{Discriminant Validity (DV)}

According to Hair et al. (2017) and Ramayah et al. (2017), who have suggested the process of assessing the DV in PLS through using three steps (criteria) approach. That criteria comprised from examining the crossloadings; Forner-Lacker criterion; and HTMT. Thus, First, for evaluating the cross-loadings, the outer loading of an item should be greater on its respective latent variable than the item's cross-loading on another latent variable. Table 3 shows that the outer loading of each indicator was greater on its respective latent variable than its crossloading on another latent variable.

Table 3 - Cross-loadings.

\begin{tabular}{|c|c|c|c|c|c|c|c|}
\hline Construct & Items & Hope & Optimism & Resilience & Self- efficacy & $\begin{array}{l}\text { Self- } \\
\text { directed }\end{array}$ & $\begin{array}{l}\text { Values- } \\
\text { driven }\end{array}$ \\
\hline \multirow{18}{*}{$\begin{array}{c}\text { Psychological } \\
\text { capital (PsyCap) }\end{array}$} & Ho1 & 0.755 & 0.271 & 0.465 & 0.523 & 0.337 & 0.373 \\
\hline & Ho3 & 0.763 & 0.384 & 0.458 & 0.421 & 0.25 & 0.335 \\
\hline & Ho4 & 0.737 & 0.342 & 0.476 & 0.462 & 0.318 & 0.321 \\
\hline & Ho5 & 0.837 & 0.478 & 0.504 & 0.522 & 0.433 & 0.448 \\
\hline & Op3 & 0.428 & 0.77 & 0.311 & 0.422 & 0.397 & 0.475 \\
\hline & Op4 & 0.322 & 0.803 & 0.27 & 0.397 & 0.361 & 0.441 \\
\hline & Op5 & 0.378 & 0.83 & 0.294 & 0.366 & 0.346 & 0.38 \\
\hline & Op6 & 0.392 & 0.768 & 0.308 & 0.375 & 0.406 & 0.417 \\
\hline & $\operatorname{Re} 1$ & 0.485 & 0.302 & 0.812 & 0.414 & 0.423 & 0.299 \\
\hline & $\operatorname{Re} 2$ & 0.581 & 0.31 & 0.817 & 0.484 & 0.477 & 0.378 \\
\hline & $\operatorname{Re} 4$ & 0.431 & 0.39 & 0.738 & 0.294 & 0.275 & 0.346 \\
\hline & $\operatorname{Re} 5$ & 0.357 & 0.109 & 0.698 & 0.261 & 0.22 & 0.261 \\
\hline & $\mathrm{Se} 1$ & 0.496 & 0.298 & 0.409 & 0.713 & 0.322 & 0.312 \\
\hline & $\mathrm{Se} 2$ & 0.519 & 0.423 & 0.396 & 0.739 & 0.286 & 0.311 \\
\hline & $\mathrm{Se} 3$ & 0.472 & 0.415 & 0.303 & 0.772 & 0.315 & 0.326 \\
\hline & $\mathrm{Se} 4$ & 0.498 & 0.359 & 0.379 & 0.816 & 0.38 & 0.388 \\
\hline & $\mathrm{Se} 5$ & 0.387 & 0.319 & 0.339 & 0.741 & 0.351 & 0.24 \\
\hline & Se6 & 0.433 & 0.401 & 0.366 & 0.727 & 0.266 & 0.394 \\
\hline \multirow{10}{*}{$\begin{array}{c}\text { Protean career } \\
\text { orientation } \\
\text { (PCO) }\end{array}$} & SD1 & 0.346 & 0.349 & 0.39 & 0.31 & 0.742 & 0.325 \\
\hline & SD2 & 0.334 & 0.279 & 0.472 & 0.299 & 0.793 & 0.3 \\
\hline & SD3 & 0.375 & 0.359 & 0.394 & 0.351 & 0.838 & 0.411 \\
\hline & SD4 & 0.293 & 0.415 & 0.346 & 0.341 & 0.768 & 0.286 \\
\hline & SD5 & 0.369 & 0.439 & 0.37 & 0.366 & 0.77 & 0.301 \\
\hline & SD6 & 0.334 & 0.406 & 0.251 & 0.336 & 0.789 & 0.396 \\
\hline & VD1 & 0.442 & 0.402 & 0.354 & 0.399 & 0.33 & 0.798 \\
\hline & VD2 & 0.411 & 0.471 & 0.372 & 0.366 & 0.4 & 0.892 \\
\hline & VD3 & 0.392 & 0.431 & 0.379 & 0.373 & 0.345 & 0.846 \\
\hline & VD4 & 0.366 & 0.508 & 0.31 & 0.336 & 0.369 & 0.813 \\
\hline
\end{tabular}

Next, in order to assess for discriminant validity, Fornell-Larcker criterion was applied where the square root of AVE of each latent variable should be greater than its correlation with another latent variable. By applying this 
approach, we found that the square root of AVE of each of the latent variables was greater than its correlation with another latent variable. The outcome is shown in the table 4.

Table 4 - Fornell-Larcker Criterion.

\begin{tabular}{lllllll}
\hline Dimensions & Hope & Optimism & Resilience & Self-directed & Self-efficacy & Values-driven \\
\hline Hope & 0.774 & \multicolumn{7}{l}{} & & & & \\
Optimism & 0.481 & 0.793 & & & & \\
Resilience & 0.615 & 0.374 & 0.768 & & & \\
Self-directed & 0.436 & 0.477 & 0.471 & 0.784 & & \\
Self-efficacy & 0.624 & 0.492 & 0.486 & 0.426 & 0.752 & \\
Values-driven & 0.48 & 0.541 & 0.422 & 0.432 & 0.439 & 0.838 \\
\hline
\end{tabular}

Finally, according to Henseler (2017) and Henseler, Ringle, and Sarstedt (2015), who recommended the utilization of Heterotrait-Monotrait ratio (HTMT) as an additional technique for assessing the discriminant validity. While, that technique of (HTMT) detects the estimation of the true correlation between two latent variables (Ramayah et al., 2017). A threshold value of 0.90 had been suggested for the HTMT (Henseler et al., 2015). If the result is above 0.90 , this shows a lack of discriminant validity. However, for this study, according to the Table 5 shows that the HTMT criterion was complied with threshold criterion which all the shown values were less than 0.90 .

Table 5 - HTMT Criterion.

\begin{tabular}{lllllll}
\hline Dimensions & Hope & Optimism & Resilience & Self-directed & Self-efficacy & Values-driven \\
\hline Hope & & & & & & \\
Optimism & 0.603 & & & & \\
Resilience & 0.781 & 0.459 & & & \\
Self-directed & 0.525 & 0.57 & 0.555 & & \\
Self-efficacy & 0.767 & 0.595 & 0.585 & 0.496 & 0.515 & \\
Values-driven & 0.587 & 0.651 & 0.514 & 0.495 & \\
\hline
\end{tabular}

\subsection{Formative Measurement Model Analysis}

PLS's scholars have suggested procedures for assessing the formative measurement model in terms of the discriminant and convergent validity evaluation (Hair et al., 2017; Hair et al., 2014; Ramayah et al., 2017). First, we ran the Smart-PLS Algorithm in order to know about the collinearity issues. Next, the inner Variance Inflation Factor (VIF) values were assessed. After that, Bootstrapping was performed to get the weights' value and t-values for each item in order to know whether the weights were significant $<0.05$ or not. Table 6 shows the significance level of all the reflective-formative measurements throughout because of the t-value $>1.96$ and sig value $<0.000$. The results indicated that there was no problem of collinearity issues with the reflective-formative construct because of the threshold value <5 (Hair et al., 2014). This means that the indicators of career success were not correlated.

Table 6 - Assessing Weights, VIF Values and t-values.

\begin{tabular}{lllccccc}
\hline $\begin{array}{l}\text { Second order } \\
\text { construct }\end{array}$ & $\begin{array}{l}\text { First order/ } \\
\text { dimensions }\end{array}$ & Items & Measure & Weights & VIF & $\begin{array}{l}\text { t-value } \\
\text { weights }\end{array}$ & p-value \\
\hline & Objective & Promotion & & 0.185 & 3.558 & $* * * 5.169$ & 0.000 \\
& & Publications & & 0.181 & 2.018 & $* * * 5.643$ & 0.000 \\
& & Pay & & 0.176 & 2.167 & $* * * 5.281$ & 0.000 \\
Career Success & & Position & \multirow{2}{*}{ Formative } & 0.203 & 4.893 & $* * * 5.646$ & 0.000 \\
& Subjective & Subjective1 & & 0.216 & 1.786 & $* * * 8.089$ & 0.000 \\
& & Subjective2 & & 0.217 & 1.986 & $* * * 7.531$ & 0.000 \\
& & Subjective4 & & 0.212 & 2.12 & $* * * 7.357$ & 0.000 \\
& & Subjective5 & & 0.18 & 1.607 & $* * * 5.059$ & 0.000 \\
\hline
\end{tabular}


Note: Critical t values $* * * 2.57$ (significance level=1\%)

\subsection{Control variables}

For assessing the effect of controlled variable on the endogenous variable (i.e. career success). The $\mathrm{R}^{2}$ result showed that gender has no effect on academics' career success because achieved (-0.094). however, the working experience and the respondent age have effect on career success where the accounted $\mathrm{R}^{2}$ was $(0.502)$ for wording experience and (0.249) for age. Therefore, the researchers have run all the model including control variables which showed that (0.346) explained by control variables (i.e. age and experience). In other words, the age and experience explain $35 \%$ of academics' career success in this model whereas the other effect explained by other variables.

\subsection{Structural Model Assessment}

For evaluating the structural model of this study, we applied the calculated to the total score of the formative and reflective items (Ramayah et al., 2017) in order to get an appropriate result after running bootstrapping for the path coefficient. Specifically, we analysed the path coefficient (Hair et al., 2017), $\mathrm{R}^{2}$ (Cohen, 1989) (Ramayah et al., 2018), and $\mathrm{Q}^{2}$ (Hair et al., 2017) (see table 7 and figure 2) to test the hypotheses constructed for this study. Table 7 shows that all the proposed hypotheses were supported because of the t-value $>1.96$ and $\mathrm{P}<0.01$. which means that PCO has a positive direct effect on PsyCap whereas PsyCap not only played a significant positive mediator on the relationship between PCO and career success but also has a direct effect on academics' career success (see discussion part).

Table 7 - Results of the Structural Model Analysis (Hypotheses Testing)

\begin{tabular}{|c|c|c|c|c|c|c|c|c|c|}
\hline Hypothesis & Effect & Relationship & $\begin{array}{l}\text { Std } \\
\text { Beta }\end{array}$ & $\begin{array}{l}\text { Std. } \\
\text { Error }\end{array}$ & t-value & Decision & $R^{2}$ & $f^{2}$ & $Q^{2}$ \\
\hline$H 1$ & & $P C O$-> PsyCap & 0.687 & 0.06 & $* * * 11.448$ & Supported & 0.471 & 0.891 & ----- \\
\hline$H 2$ & Direct & $\begin{array}{l}\text { PsyCap -> Career } \\
\text { Success }\end{array}$ & 0.479 & 0.091 & $* * * 5.262$ & Supported & ----- & 0.151 & 0.272 \\
\hline$H 3$ & Indirect & $\begin{array}{l}P C O \text {-> PsyCap - } \\
>\text { Career Success }\end{array}$ & 0.329 & 0.075 & $* * * 4.375$ & Supported & ----- & ----- & ----- \\
\hline
\end{tabular}

Note: $* * * \mathrm{p}<0.005, * * \mathrm{p}<0.01, * \mathrm{P}<0.05$. PCO Protean Career Orientation, PsyCap Psychological Capital.

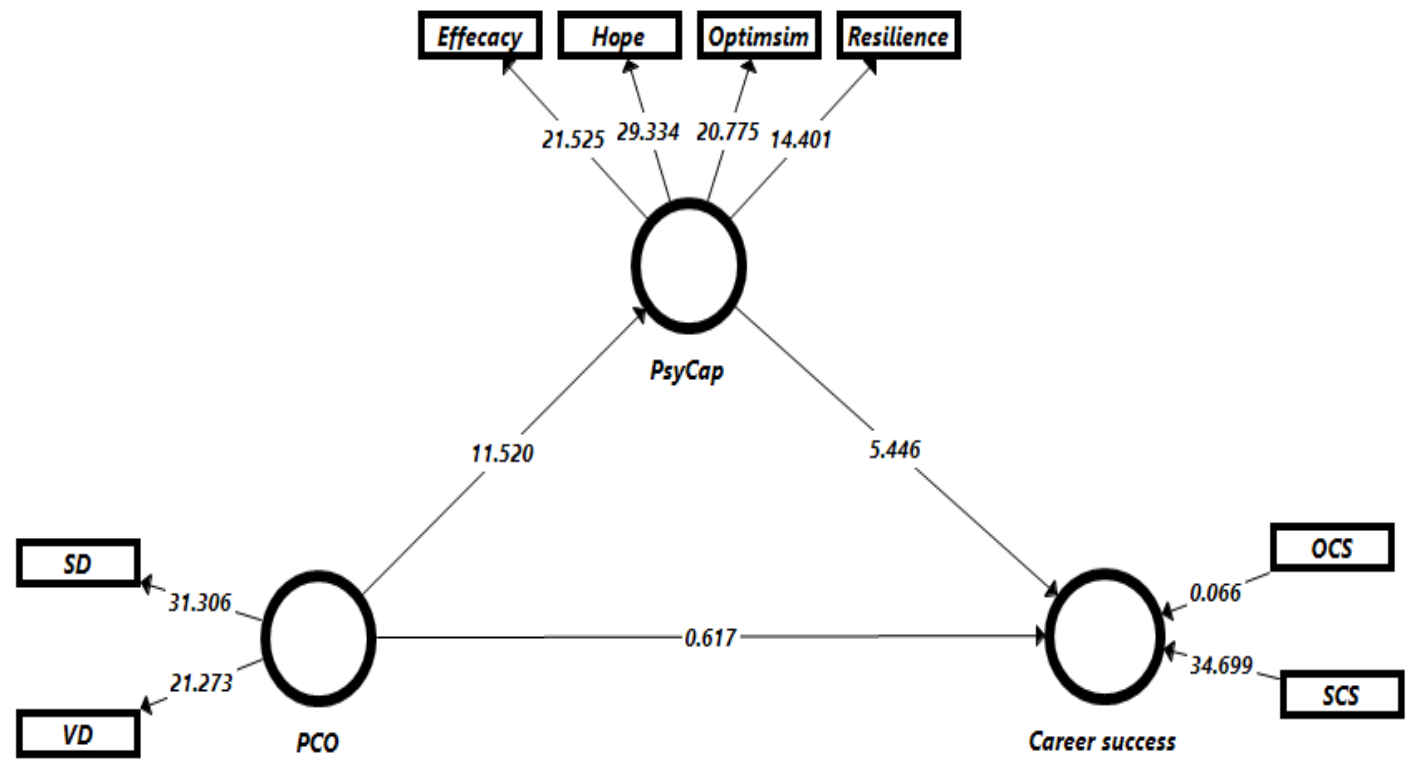

Fig. 2 - Showing the statistical model of the study 


\subsection{Discussion and Conclusion}

The purpose of this study was to investigate the mediator role of PsyCap on the relationship between PCO and CS among academic staff in public universities in Sudan. The results of the study indicated that; firstly, PCO was positively related to PsyCap resources which are hope, efficacy, resilience, and optimism (HERO). This result enhances the idea of Hall and his colleagues (2006) which explains that the PCO helps an individual to engage in the self-learning process. This, in turn, will increase the individual's psychological resources. Moreover, the previous work has focused on the indirect effects of PCO on PsyCap rather than the direct effects. For example, DiRenzo (2010) and Direnzo et al. (2015) have investigated the role of PCO in career capital (including PsyCap) via career planning. whereas, this study filled the gap in the current literature by finding the direct effect of PCO on PsyCap resources.

Secondly, PsyCap resources (HERO) have a strong positive relationship with the academics' career success. This result was congruent with (Karatepe \& Karadas, 2015; Schulz et al., 2014) who have verified in their studies that PsyCap is related to the subjective career success. Nevertheless, the mixed results from previous studies have also suggested some dimensions of PsyCap were more relevant to career success than others. For example, (Karatepe \& Karadas, 2015) found that only optimism has a strong effect on career success where other resources were not, however, this study found all the PsyCap resources has a positive effect on academics' career success.

Thirdly, PsyCap plays an important mediator role between PCO and academics' career success (see figure 2). This result was unique because it confirms that academic staff who are protean oriented (i.e., have self-management and intrinsic values) need to possess PsyCap resources (HERO) for achieving a success in their career. Coincidently, this finding is in lined with the COR theory (Hobfoll, 1989) which explains that people who gain resources, such resources will help them to generate additional resources that can help them to ultimately achieve their goals. In contrast, the previous studies concentrated on investigating PCO with subjective (psychological) success (e.g. Abele \& Spurk, 2009 and Volmer \& Spurk, 2011). Next, Hall (2004) established that PCO led to psychological success rather than objective career success. However, Hall et al. (2018) suggested that PCO is able to predict both subjective and objective career success. A uniqueness of our study was that we measured career success as a formative construct based on the theory of measurement in Smart-PLS. We performed as such because it was difficult to combine objective and subjective measures without testing them in a formative format. On the contrary, previous studies measured career success as a reflective construct (Abu Said et al., 2015). That could be because the study had used the AMOS software in analysing such a construct. However, the Smart-PLS has been found to be more precise in analysing formative construct (Hair et al., 2014). In conclusion, this study focused on investigating the role of PsyCap resources as a mechanism of the PCO to stimulate career success.

Finally, the results evidenced the substantial contribution of PsyCap in explaining the relationship between PCO and career success in the context of the academia. This fresh result witnessed the application of the COR theory in the field of the academia. For example, the academic staff who are protean oriented need to increase their level of psychological resources (that is, hope; efficacy; resilience; and optimism) in order to achieve success in their career. Another uniqueness of this study is that it has filled the gap of the career success concept by combining both career success dimensions in one model. The contribution is also awarded on the statistics part as the career success construct was assessed as a formative rather than as reflective, to provide this study with a specific result. The contribution of this study has also extended beyond the boundary as it is not only beneficial for the academic staff but also useful for a university's development. For achieving the latter goal, universities need to conduct training for the academics to increase their awareness of the PCO as this can create a culture of proactive and productive in the academic lifestyle.

\section{The Significance of the Study}

This study inspires as it contributes to the theory and practice in the area of career success of academics in the universities. From the theoretical perspective, this study experimented with positive psychological factors that are believed to influence the career success of academics in Sudan. These factors are identified as protean career orientation (self-directed and intrinsic values), and psychological capital (hope, efficacy, resilience, and optimism) and its impact on the career success of academics. It appears that to date these factors have received no attention from previous researchers in the Non-western context such as Sudan.

From the practical perspective, the findings will be beneficial not only to the academic staff but also to the leaders of public universities in Sudan as it increases their understanding of the psychological resources that have the potential to generate career success of the academics. Moreover, the study supported the proposal that institutions pay attention to developing employee psychological resources (e.g., HERO) as this could increase the success of academics in their career. Finally, this study also provided direction for future research in that researchers use a combination of career success dimensions for the results to be more accurate and reliable. 


\section{Limitation and Future Study}

The positive psychology movement by Seligman (2002) has three streams (positive emotions, positive individual traits, and positive institutions). This study focused on the positive individual traits only (i.e., PCO and PsyCap's resources) and their influence on the career success of academics from the COR theory perspective. In addition, this study only investigated the full-time lecturers in public universities in Sudan. Therefore, these limitations may open new directions for researchers and academicians in addressing academics' career success from other positive psychological predictors, for example, positive emotions or positive institutions. In addition, the future research may apply other theories that address career success such as the goal-setting theory.

\section{References}

Abele, A. E., \& Spurk, D. (2009a). How do objective and subjective career success interrelate over time? Journal of Occupational and Organizational Psychology, 82, 803-824.

Abele, A. E., \& Spurk, D. (2009b). The longitudinal impact of self-efficacy and career goals on objective and subjective career success. Journal of Vocational Behavior Journal, 74(1), 53-62.

Abele, A. E., Hagmaier, T., \& Spurk, D. (2016). Does Career Success Make You Happy? The Mediating Role of Multiple Subjective Success Evaluations. Journal of Happiness Studies, 17(4), 1615-1633.

Abele, A. E., Spurk, D., \& Volmer, J. (2011). The construct of career success: measurement issues and an empirical example. Journal for Labour Market Research, 43(3), 195-206.

Abessolo, M., Andreas, H., \& Jérôme, R. (2017). Work values underlying protean and boundaryless career orientations. Career Development International, 22(3), 1-37.

Abu Said, A., Mohd Rasdi, R., Abu Samah, B., Silong, A. D., \& Sulaiman, S. (2015). A career success model for academics at Malaysian research universities. European Journal of Training and Development, 39(9), 815-835.

Anderson, J., \& Gerbing, D. W. (1988). Structural equation modeling in practice: A review and recommended a two-step approach. Psychological Bulletin, 103(3), 411-423.

Anderson, N., \& Park, R. (1923). The Hobo: The Sociology of the Homeless Man; A Study Prepared for the Chicago Council of Social Agencies Under the Direction of the Committee on.

Arthur, M. B., Khapova, S. N., \& Wilderom, C. P. M. (2005). Career success in a boundaryless career world. Journal of Organizational Behavior, 26, 177-202.

Ballout, H. I. (2007). Career success the effects of human capital, person-environment fit and organizational support. Journal of Managerial Psychology, 22(8), 741-765.

Briscoe, J. P., \& Hall, D. T. T. (2006). The Interplay of Boundaryless and Protean Careers: Combinations and Implications. Journal of Vocational Behavior ·, 69, 4-18.

Briscoe, J. P., Hall, D. T., \& Frautschy DeMuth, R. L. (2006). Protean and boundaryless careers: An empirical exploration. Journal of Vocational Behavior, 69(1), 30-47.

Colakoglu, S. N. (2011). The impact of career boundarylessness on subjective career success: The role of career competencies, career autonomy, and career insecurity 2 . Journal of Vocational Behavior, 79(1), 47-59.

DiRenzo, M. S. (2010). An Examination of the Roles of Protean Career Orientation and Career Capital on Work and Life Outcomes. Proquest. Drexel University.

Direnzo, M. S., \& Greenhaus, J. H. (2011). Job search and voluntary turnover in a boundaryless world: A control theory perspective. Academy of Management Review, 36(3), 567-589. 
Direnzo, M. S., Greenhaus, J. H., \& Weer, C. H. (2015). Relationship between protean career orientation and work-life balance: A resource perspective. Journal of Organizational Behavior, 36(4), 538-560.

Erdfelder, E., FAul, F., Buchner, A., \& Lang, A. G. (2009). Statistical power analyses using G*Power 3.1: Tests for correlation and regression analyses. Behavior Research Methods, 41(4), 1149-1160.

Gefen, Rigdon, \& Straub. (2011). Editor's Comments: An Update and Extension to SEM Guidelines for Administrative and Social Science Research. MIS Quarterly, 35(2), iii.

Golper, T. A., \& Feldman, H. I. (2008). New challenges and paradigms for mid-career faculty in academic medical centers: Key strategies for success for mid-career medical school faculty. Clinical Journal of the American Society of Nephrology, 3(6), 1870-1874.

Granrose, C. S., \& Baccili, P. A. (2006). Do psychological contracts include boundaryless or protean careers? Career Development International, 11(2), 163-182.

Greenhaus, J. H., Parasuraman, S., \& Wormley, W. M. (1990). Effects of Race on Organizational Experiences, Job Performance Evaluations, and Career Outcomes. Academy, The Journal, Management, 33(1), 64-86.

Grimland, S., Vigoda-Gadot, E., \& Baruch, Y. (2012). Career attitudes and success of managers: the impact of chance event, protean, and traditional careers. International Journal of Human Resource Management, 23(6), 1074-1094.

Gubler, M., Arnold, J., \& Coombs, C. (2014). Reassessing the protean career concept: empirical findings, conceptual components, and Measurement. Journal of Organizational Behavior, 35(S1), S23-S40.

Gulyani, G., \& Bhatnagar, J. (2017). Mediator analysis of passion for work in Indian millennials. Career Development International, 22(1), 50-69.

Haber, A., \& Bertone, A. (2016). Protean career model. The Encyclopedia of Adulthood and Aging, (May), 1-4.

Hair, J. F., Hult, G. T. M., Ringle, C. M., \& Sarstedt, M. (2017). A Primer on Partial Least Squares Structural Equation Modeling (PLS-SEM). Sage Publication.

Hair, J. J. F., Sarstedt, M., Hopkins, L., \& Kuppelwieser, V. G. (2014). A Primer on Partial Least Squares Structural Equation Modeling. Sage, Thousand Oaks, CA.

Hall, D. T. (1996). Protean Careers of the 21st Century. Academy of Educational Leadership Journal, 10(4), 8-16.

Hall, D. T. (2004). The protean career: A quarter-century journey. Journal of Vocational Behavior, 65(1), 1-13.

Hall, D. T., \& Chandler, D. E. (2005). Psychological Success: When the Career Is a Calling. Journal of Organizational Behavior, 26(2), 155-176.

Hall, D. T., Yip, J., \& Doiron, K. (2018). Protean careers at work: Self-direction and values orientation in psychological success. Annual Review of Organizational Psychology and Organizational Behavior, 5, 6.1-6.28.

Henseler, J. (2017). Bridging Design and Behavioral Research with Variance-Based Structural Equation Modeling. Journal of Advertising, 46(1), 178-192.

Henseler, J., Ringle, C. M., \& Sarstedt, M. (2015). A new criterion for assessing discriminant validity in variancebased structural equation modeling. Journal of the Academy of Marketing Science, 43(1), 115-135.

Herrmann, A., Hirschi, A., \& Baruch, Y. (2015). The protean career orientation as predictor of career outcomes: Evaluation of incremental validity and mediation effects. Journal of Vocational Behavior, 88, 205-214.

Hobfoll, S. E. (1989). Conservation of resources: A new attempt at conceptualizing stress. American Psychologist, 44(3), 513-524. 
Hobfoll, S. E., Johnson, R. J., Ennis, N., \& Jackson, A. P. (2003). Resource loss, resource gain, and emotional outcomes among inner-city women. Journal of Personality and Social Psychology, 84(3), 632-643.

Hughes, E. C. (1937). Institutional Office and the Person. American Journal of Sociology, 43(3), 404-413.

Hughes, E. C. (1958). Men and their work Glencoe, IL: Free Press.

Kaderli, R., Muff, B., Stefenelli, U., \& Businger, A. (2011). Female surgeons' mentoring experiences and success in an academic career in Switzerland. Swiss Medical Weekly, 141(July), 1-8.

Karatepe, O. M., \& Karadas, G. (2015). Do psychological capital and work engagement foster frontline employees' satisfaction? International Journal of Contemporary Hospitality Management, 27(6), 1254-1278.

Khan, M. L., Salleh, R., \& Hemdi, M. A. B. (2016). Effect of protean career attitudes on organizational commitment of employees with moderating role of organizational career management. International Review of Management and Marketing, 6(4), 155-160.

Kiong, T. P., \& Yin-Fah, B. C. (2016). Exploring factors towards career success in Malaysia. International Business Management, 10(17), 3936-3943.

Krishna, A. (2016). Psychological Capital and Protean Career Orietntation on Employee Loyality.

Leahey, E., Crockett, J. L., \& Hunter, L. A. (2008). Gendered Academic Careers: Specializing for Success? Oxford University Press, 86(3), 1273-1309.

Luthans, F., Avolio, B. J., Avey, J. B., \& Norman, S. M. (2007). Positive Psychological Capital: Measurement and Relationship with Performance and Satisfaction Positive Psychological Capital: Measurement and Relationship with. Personal Psychology, 60, 541-572.

Luthans, F., Avolio, B. J., Walumbwa, F. O., \& Li, W. (2005). The Psychological Capital of Chinese Workers: Exploring the Relationship with Performance. Management and Organization Review, 1(2), 249-271.

Luthans, Luthans, K. W., \& Luthans, B. C. (2004). Positive psychological capital: Beyond human and social capital. Business Horizons, 47(1), 45-50.

Ng, T. W. H., \& Feldman, D. C. (2014). Subjective career success: A meta-analytic review. Journal of Vocational Behavior,85(2), 169-179.

Ng, T. W. H., Eby, L., Sorensen, K. L., \& Feldman, D. C. (2005). Predictors of Objective and Subjective Career Success: A Meta-Analysis. Personnel Psychology, 58, 367-408.

Ng, T. W. H., Eby, L., Sorensen, K. L., \& Feldman, D. C. (2005). Predictors of Objective and Subjective Career Success: A Meta- Analysis. Personnel Psychology, 58, 367-408.

Ngo, H. Y., Foley, S., Ji, M. S., \& Loi, R. (2014). Linking Gender Role Orientation to Subjective Career Success: The Mediating Role of Psychological Capital. Journal of Career Assessment, 22(2), 290-303.

Otto, K., Roe, R., Sobiraj, S., Baluku, M. M., \& Garrido Vásquez, M. E. (2017). The impact of career ambition on psychologists' extrinsic and intrinsic career success. Career Development International, 22(1), 23-36.

Ramayah, T., Jasmine, Y. A. L., Ahmad, N. H., Halim, H. A., \& Rahman, S. A. (2017). Testing a Confirmatory model of Facebook Usage in SmartPLS using Consistent PLS. International Journal of Business and Innovation, 3(2), 1-14.

Ramayah, T., Lee, J. W. C., \& In, J. B. C. (2011). Network collaboration and performance in the tourism sector. Service Business, 5(4), 411-428.

Reardon, R., Lenz, J., Sampson, J., \& Peterson, G. (1999). Career development and planning: A comprehensive approach. 
Ringle, C. M., Da Silva, D., \& Bido, D. D. S. (2014). Structural Equation Modeling with the Smartpls. Revista Brasileira de Marketing, 13(2), 56-73.

Ringle, C. M., Wende, S., \& Becker, J.-M. (2015). SmartPLS 3. Hamburg. SmartPLS Retrieved from http://www.smartpls.com.

Riordan, S., \& Louw-Potgieter, J. (2011). Career success of women academics in South Africa. South African Journal of Psychology, 41(2), 157-172.

Robinson, D. A., \& Cooper, S. E. (1984). The influence of self-concept on academic success in technological careers. Journal of College Student Personnel.

Rowe, K. (2013). Psychological Capital and Employee Loyalty: The Mediating Role of. Dissertation. University of Canterbury.

Santos, G. G., \& Santos, G. G. (2016). experiences Career barriers influencing career success A focus on academics' perceptions and experiences. Career Development International, 21(1), 85-104.

Schulz, S. A., Luthans, K. W., \& Messersmith, J. G. (2014). Psychological capital. International Journal of Physical Distribution \& Logistics Management, 44(8/9), 621- 634.

Seibert, S. E., Crant, J. M., \& Kraimer, M. L. (1999). Proactive Personality and Career Success. Journal of Applied Psychology, 84(3), 416-427.

Seligman, M. E. P. (2002). Positive psychology, positive prevention, and positive therapy. In Handbook of positive psychology (pp. 3-9).

Sen Chandrani, \& Hooja Himangini. (2015). Developing Indian human resource: Role of psychological capital and protean career orientation. Indian Journal of Positive Psychology, 6(3), 311-314.

Shen, Y., Demel, B., Unite, J., Briscoe, J. P., Hall, D. T., Chudzikowski, K., ... Zikic, J. (2015). Career success across 11 countries: implications for international human resource management. The International Journal of Human Resource Management, 26(13), 1753- 1778.

Stumpf, S. A., \& Tymon, W. G. (2012). The effects of objective career success on subsequent subjective career success. Journal of Vocational Behavior, 81((3)), 345-353.

Tehseen, S., Sajilan, S., Gadar, K., \& Thurasamy, R. (2017). Assessing Cultural Orientation as a ReflectiveFormative Second Order Construct -A Recent PLS-SEM Approach. Review of Integrative Business and Economics ResearchOnlineCDROM, 6(2), 38-63.

Valcour, M., \& Ladge, J. (2008). Family and career path characteristics as predictors of women â€ $€^{\mathrm{TM}}$ s objective and subjective career success: Integrating traditional ... Journal of Vocational Behavior, 73(2), 300-309.

van Dierendonck, D., \& van der Gaast, E. (2013). Goal orientation, academic competences and early career success. Career Development International, 18(7), 694-711.

Volmer, J., \& Spurk, D. (2011). Protean and boundaryless career attitudes: relationships with subjective and objective career success. Zeitschrift Für ArbeitsmarktForschung, 43, 207- 218.

Vos, A. De, \& Soens, N. (2008). Protean attitude and career success: The mediating role of self-management. Journal of Vocational behavior, 73(3), 449-456. 